ACADEMIA ROMÂNĂ

Revue Roumaine de Chimie

http://web.icf.ro/rrch/
Rev. Roum. Chim.

2020, 65(7-8), 761-765

DOI: $10.33224 /$ rrch.2020.65.7-8.15

\title{
MONONUCLEAR LANTHANIDE(III) COMPLEXES WITH TRIPODAL LIGANDS AS AMMONIUM CATION RECEPTORS
}

\author{
Andrei COSTACHE and Augustin M. MĂDĂLAN* \\ Inorganic Chemistry Department, Faculty of Chemistry, University of Bucharest, Dumbrava Rosie 23, 020464-Bucharest, Roumania
}

Received May 4, 2020

Synthesis and crystal structures of the mononuclear complexes [Er(valtren)] (1) and $\left[\mathrm{Yb}(\right.$ valtren) $]$ (2), $\mathrm{H}_{3}$ valtren is the Schiff base derived from $o$-vanillin and tris(2aminoethyl)-amine, are reported herein. The [Er(valtren)] (1) mononuclear complex was used as receptor for ammonium cation and the supramolecular complex $\left[\right.$ Er(valtren) $\left.\left\{\mathrm{NH}_{4}\right\}\right]\left(\mathrm{PF}_{6}\right) \cdot 3 \mathrm{CH}_{3} \mathrm{CN}$ (3) was structurally characterized by $\mathrm{X}$-ray diffraction on single crystal. The ammonium cation is hosted in the external compartment of the tripodal bicompartmental ligand.

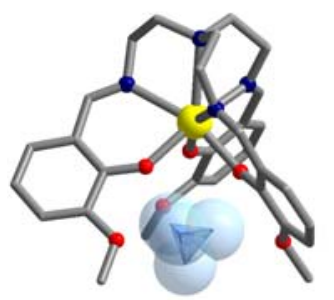

\section{INTRODUCTION}

The design and synthesis of molecular receptors able to recognize particular chemical species require topological control of the molecular fragments involved in the non-covalent interactions, which can offer a good electronic and steric complementarity between host and guest. In metallosupramolecular chemistry, the metal ions play a double role: $i$ ) structural (organising the ligand), and ii) functional (carrying magnetic, optical, redox or catalytic properties). Schiff-bases derived from $o$-vanillin and diamines are easily accessible ligands and usually behave as bicompartmental ligands, allowing the synthesis of heterobinuclear $3 \mathrm{~d}-4 \mathrm{f}$ complexes ${ }^{1}$ or $3 \mathrm{~d}-$ 3 d' complexes. ${ }^{2}$ In mononuclear complexes with this type of ligands, the metal ion is hosted into the $\mathrm{N}_{2} \mathrm{O}_{2}$ compartment (Scheme 1a) and the larger vacant $\mathrm{O}_{2} \mathrm{O}_{2}{ }_{2}$ compartment can act as a receptor not only toward other metal ions, but also toward hydrogen bond donors (e.g. the aqua ligand ${ }^{3,4}$ or ammonium cation $^{5}$ ). These planar tectons can be also used in combination with 4-aminopyridine, which acts as coordinating ligand and hydrogen bonds donor, to build various supramolecular architectures: rectangles, zigzag chains or ladders. ${ }^{6}$ The three dimensional version of these bicompartimental ligands can be obtained by reacting $O$-vanillin with tris(2-aminoethyl)-amine (Scheme 1b). Generally, the tripodal ligands were used as receptors for different chemical species: transition metal ions, ${ }^{7}$ lanthanide ions, ${ }^{8}$ anions, ${ }^{9}$ or cations and anions in the same time. ${ }^{10}$ In the particular case of the tripodal Schiff base ligand derived from $o$-vanillin and tris(2aminoethyl)-amine, $\mathrm{H}_{3}$ valtren, the compartments can host one ${ }^{11}$ or two lanthanide ions. ${ }^{8 \mathrm{a}, \mathrm{b}}$

In this paper we report on crystal structures of the mononuclear complexes of the anionic valtren ${ }^{3-}$ tripodal ligand with erbium(III) and ytterbium(III) ions, [Er(valtren)] (1) and [Yb(valtren)] (2), and the use of the $[\operatorname{Er}($ valtren)] complex as receptor for the ammonium cation.

\footnotetext{
*Corresponding author: augustin.madalan@chimie.unibuc.ro
} 


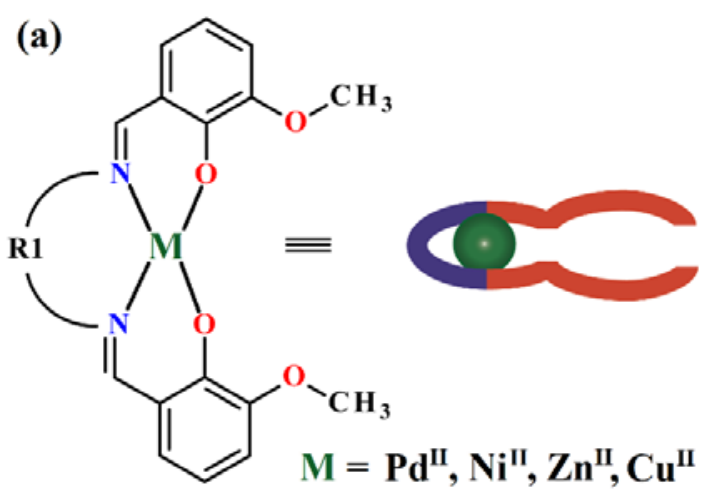

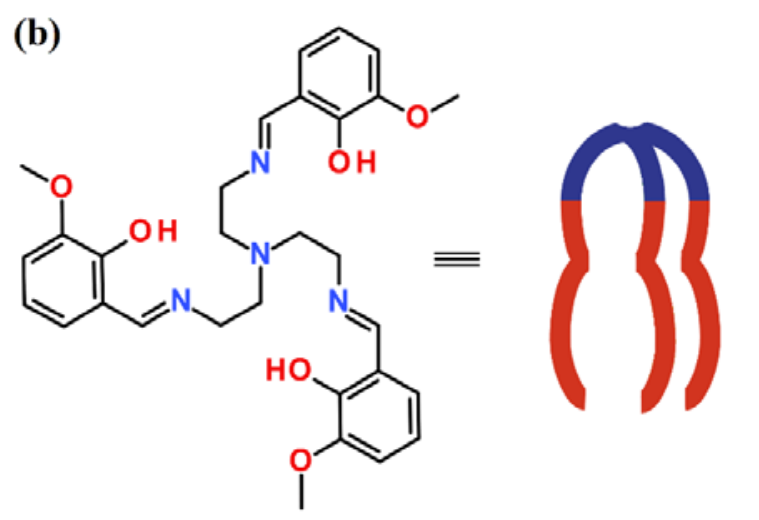

Scheme 1

\section{RESULTS AND DISCUSSION}

The synthesis of mononuclear complexes of valtren anionic tripodal ligand with various lanthanide(III) ions, [Ln(valtren)], was already reported, ${ }^{11}$ but the structural information concerning this series of compounds was gathered only by powder X-ray diffraction. Herein we present the structural characterization of [Er(valtren)] (1) and [Yb(valtren)] (2) complexes by X-ray diffraction on single crystal. The two compounds are isostructural and crystallize in the trigonal $P-3$ space group. Below we will describe only the structure of compound $\mathbf{1}$.

In the [Er(valtren)] mononuclear complex, the lanthanide ion has a coordination number seven and is located in the inner compartment of the ligand surrounded by the four nitrogen atoms (three imino and one amino) and the three phenoxo oxygen atoms (Figure 1). The external compartment of the ligand delimited by the three phenoxo and three methoxy oxygen atoms is empty. The lanthanide ion and amino nitrogen atom (N1) lie on a $C_{3}$ axis of symmetry. The Ln-N bond lengths in compounds $\mathbf{1}$ and $\mathbf{2}$ are: Er1-N1 = 2.874(14), Er1-N2 = 2.447(10) $\AA$, respectively $\mathrm{Yb} 1-\mathrm{N} 1=2.902(8)$ and $\mathrm{Yb} 1-\mathrm{N} 2=2.432(5) \AA$. The Ln-O bond lengths are: Er1-O1 $=2.178(7) \AA$ in 1 and $\mathrm{Yb} 1-\mathrm{O} 1=2.166(3) \AA$ in 2.

The molecule has an overall conical shape. The analysis of the packing diagrams shows that the molecules form piles of cones running along the crystallographic $c$ axis. The cones have the same orientation within the pile but alternating in neighbouring piles (Figure 2).

The existence of the empty external compartment containing six oxygen atoms (potentially hydrogen bonds acceptors) prompted us to attempt recognition of a hydrogen bond donor in this cavity of the mononuclear complexes. Because the $[\operatorname{Ln}($ valtren $)]$ molecules present a $C_{3}$ axis of symmetry the ammonium cation is a good candidate to be recognized in the external compartment of the ligand by hydrogen interactions.
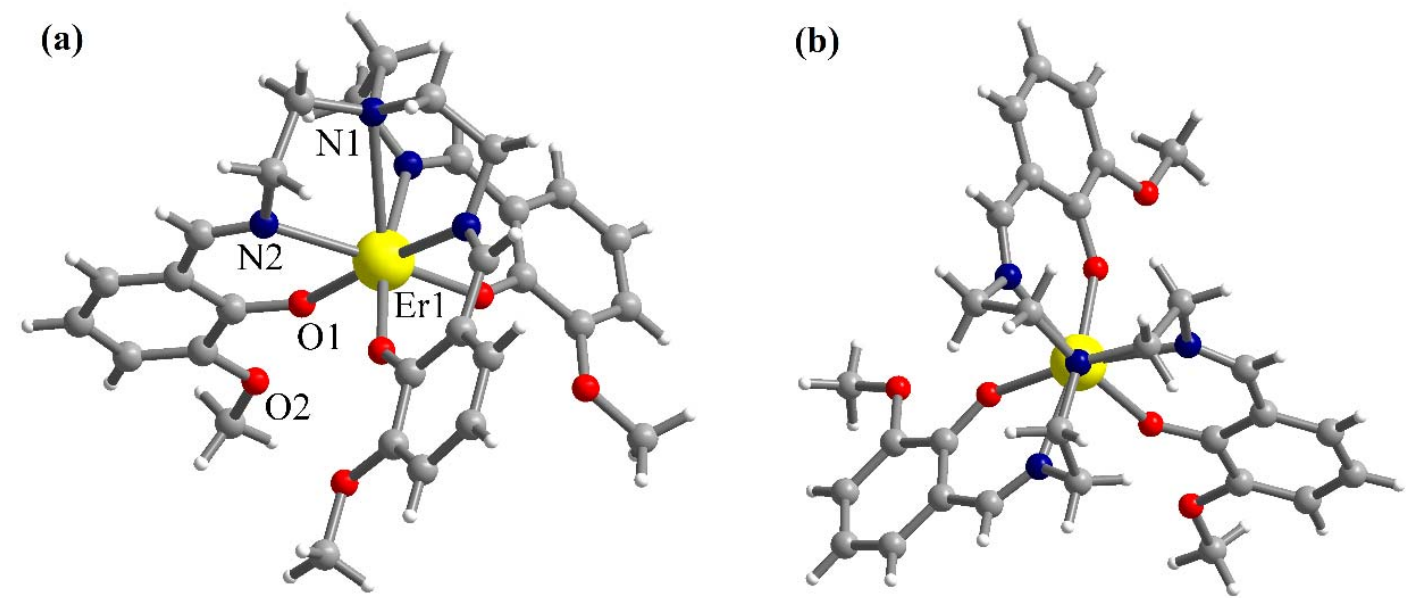

Fig. 1 - (a) Perspective view and (b) top view (along the $C_{3}$ axis of the molecule) of the molecular structure of $\mathbf{1}$ determined by X-ray diffraction on single crystal. 


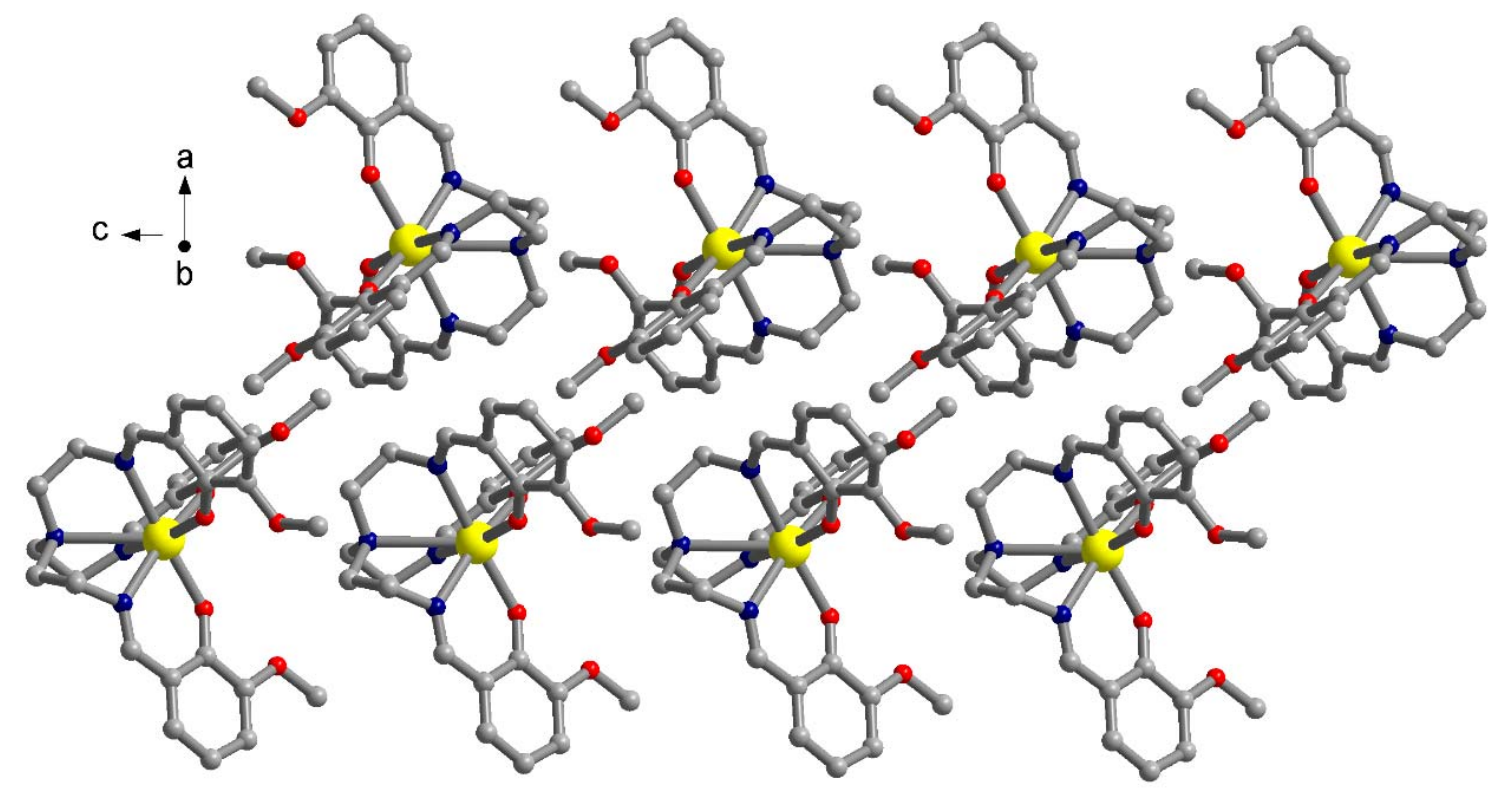

Fig. 2 - Packing diagram in crystal 1 showing two neighbouring columns of [Er(valtren)] molecules running along the crystallographic $c$ axis.
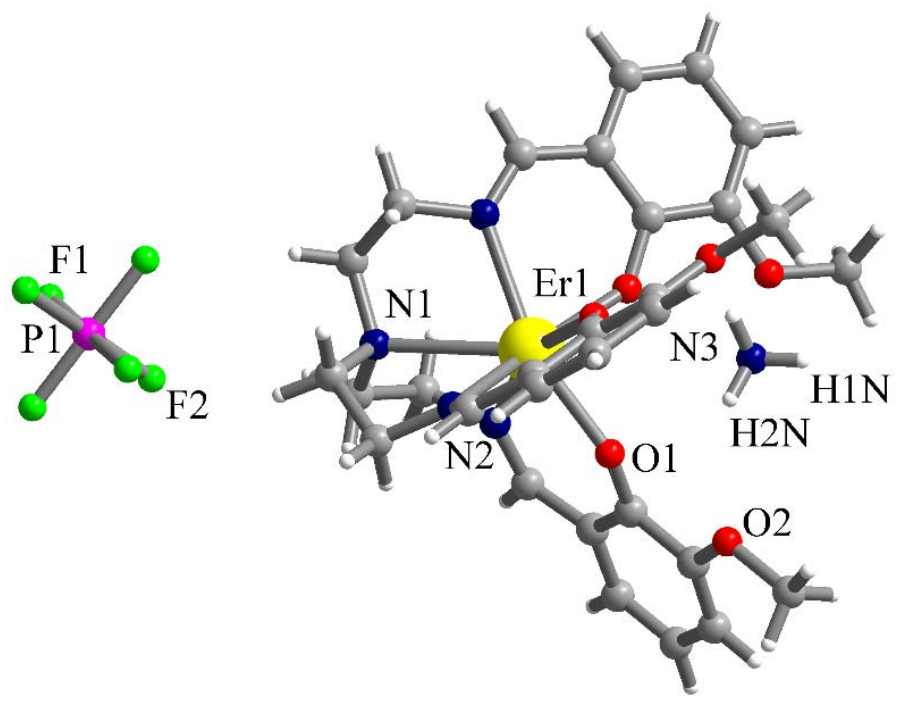

Fig. 3 - Perspective view of the supramolecular complex [Er(valtren) $\left.\left\{\mathrm{NH}_{4}\right\}\right]\left(\mathrm{PF}_{6}\right)$ in crystal $\mathbf{3}$ (the acetonitrile solvent molecules were omitted for clarity).

By stirring equimolar amounts of 1 and $\mathrm{NH}_{4} \mathrm{PF}_{6}$ in acetonitrile, the turbid mixture turns to a clear solution after 20-30 minutes. The slow evaporation at room temperature of the clear solution affords the yellow crystals of the supramolecular complex $\left[\right.$ Er(valtren) $\left.\left\{\mathrm{NH}_{4}\right\}\right]\left(\mathrm{PF}_{6}\right) \cdot 3 \mathrm{CH}_{3} \mathrm{CN}(3)$ after one week.

The structural investigation by X-ray diffraction on single crystal confirms that the [Er(valtren)] moiety still possesses the $C_{3}$ symmetry and the ammonium cation is located in the external compartment of the ligand (Figure 3). The Er(III) ion is also heptacoordinated by four nitrogen atoms (three imino and one amino) and three phenoxo oxygen atoms. The bond lengths for the coordination environment are Er1-N1 $=2.701(9)$, $\mathrm{Er} 1-\mathrm{N} 2=2.458(5)$ and $\mathrm{Er} 1-\mathrm{O} 1=2.193(4) \AA$. The $\mathrm{P} 1, \mathrm{~N} 1, \mathrm{Er} 1, \mathrm{~N} 3$ and $\mathrm{H} 1 \mathrm{~N}$ atoms lie on the same $C_{3}$ axis of symmetry.

The distances for the hydrogen interactions are: (N3) $\mathrm{H} 2 \mathrm{~N} \cdots \mathrm{O} 1=2.48 \AA$ and $(\mathrm{N} 3) \mathrm{H} 2 \mathrm{~N} \cdots \mathrm{O} 2=2.43$ $\AA$, while the corresponding angles are: N3$\mathrm{H} 2 \mathrm{~N} \cdots \mathrm{O} 1=119.2^{\circ}$ and $\mathrm{N} 3-\mathrm{H} 2 \mathrm{~N} \cdots \mathrm{O} 2=139.8^{\circ}$.

In crystal 3, the conical complexes are organized in base to base pairs formed by two cones with opposite orientation. Between the bases of the cones are located the crystallization acetonitrile molecules and on the top of the cones are placed the $\mathrm{PF}_{6}{ }^{-}$anions (Figure 4). 

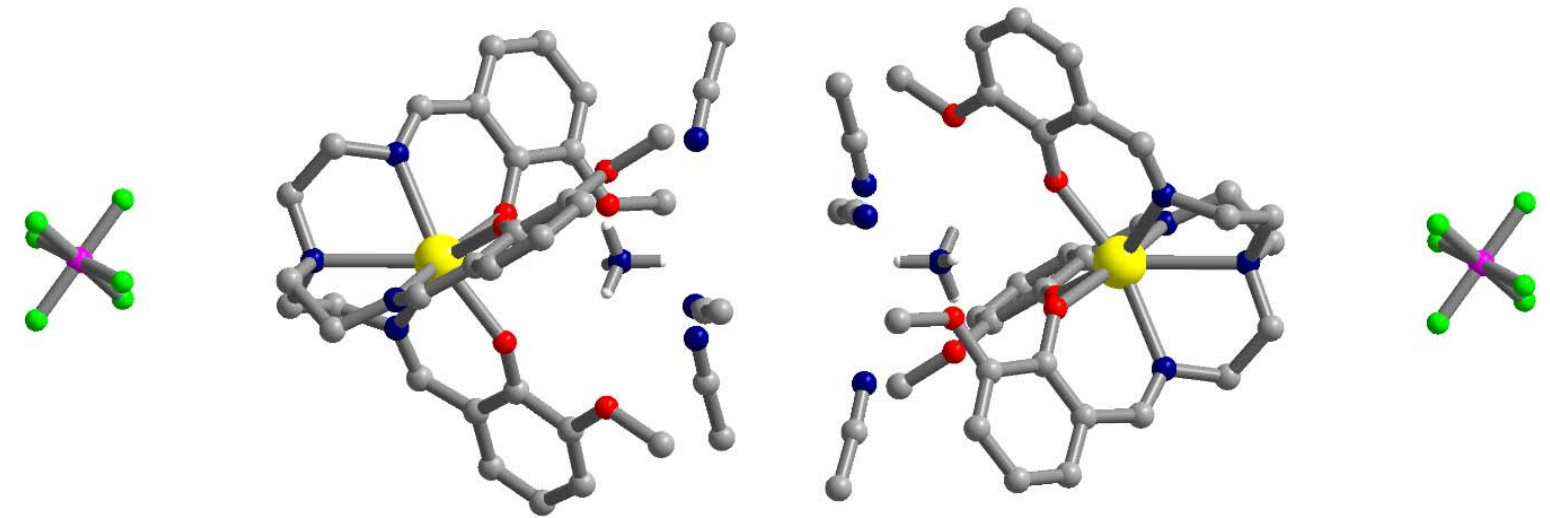

Fig. 4 - Packing diagram in crystal $\mathbf{3}$ showing a pair of supramolecular complexes.

\section{EXPERIMENTAL}

\section{Materials and methods}

\section{Synthesis of the complexes}

All the chemicals used as well as all the solvents were purchased from commercial sources. All manipulations were performed under aerobic conditions.

The mononuclear complexes [Er(valtren)] (1) and $[\mathrm{Yb}($ valtren) $]$ (2) were obtained using the same synthetic procedure: $0.3 \mathrm{mmol}$ of $o$-vanillin were added to $100 \mathrm{~mL}$ solution containing $0.1 \mathrm{mmol}$ of tris(2-aminoethyl)-amine in a mixture of $\mathrm{CH}_{3} \mathrm{OH}$ and $\mathrm{CHCl}_{3}$ (1:1). Subsequently, $0.1 \mathrm{mmol}$ of $\mathrm{Er}\left(\mathrm{NO}_{3}\right)_{3} \cdot 5 \mathrm{H}_{2} \mathrm{O}$, respectively $\mathrm{Yb}\left(\mathrm{NO}_{3}\right)_{3} \cdot 5 \mathrm{H}_{2} \mathrm{O}$, and $0.5 \mathrm{mmol}$ of triethylamine were added to the reaction mixtures and stirred for one hour. By slow evaporation of the solutions the yellow needle like crystals of $\mathbf{1}$ and $\mathbf{2}$ were obtained. The crystals were collected by filtration and washed with diethyl ether.

Selected IR data for 1 and 2 (KBr pellet, $\left.\mathrm{cm}^{-1}\right)$ : 1 - 3050w, $2926 \mathrm{w}, 1626 \mathrm{vs}, 1597 \mathrm{~m}, 1547 \mathrm{w}, 1470 \mathrm{~s}, 1446 \mathrm{~s}, 1407 \mathrm{~m}, 1333 \mathrm{~s}$, $1241 \mathrm{~s}, 1219 \mathrm{~s}, 1166 \mathrm{w}, 1083 \mathrm{w}, 1064 \mathrm{w}, 1034 \mathrm{w}, 967 \mathrm{w}, 859 \mathrm{w}$, $741 \mathrm{~m}, 629 \mathrm{w}, 536 \mathrm{w} ; 2-3413 \mathrm{w}, 3052 \mathrm{w}, 2928 \mathrm{w}, 2856 \mathrm{w}$, $1626 \mathrm{vs}, 1597 \mathrm{w}, 1548 \mathrm{w}, 1471 \mathrm{~s}, 1448 \mathrm{~s}, 1407 \mathrm{~m}, 1334 \mathrm{~s}, 1241 \mathrm{~s}$,
$1221 \mathrm{~s}, 1166 \mathrm{w}, 1083 \mathrm{w}, 1063 \mathrm{w}, 1034 \mathrm{w}, 968 \mathrm{w}, 918 \mathrm{w}, 861 \mathrm{w}$, $745 \mathrm{~m}, 627 \mathrm{w}, 536 \mathrm{w}$.

The

supramolecular

complex

[Er(valtren) $\left.\left\{\mathrm{NH}_{4}\right\}\right]\left(\mathrm{PF}_{6}\right) \cdot 3 \mathrm{CH}_{3} \mathrm{CN}(\mathbf{3})$ was obtained as yellow crystals by slow evaporation at room temperature of the solution containing $0.05 \mathrm{mmol}$ of [Er(valtren)] and $0.05 \mathrm{mmol}$ of $\mathrm{NH}_{4} \mathrm{PF}_{6}$ in $75 \mathrm{~mL}$ of acetonitrile. Selected IR data for 3 $\left(\mathrm{KBr}\right.$ pellet, $\left.\mathrm{cm}^{-1}\right): 3647 \mathrm{w}, 3333 \mathrm{w}, 3191 \mathrm{w}, 2904 \mathrm{w}, 2843 \mathrm{w}$, $1621 \mathrm{vs}, 1551 \mathrm{~m}, 1469 \mathrm{~s}, 1452 \mathrm{~s}, 1408 \mathrm{~m}, 1317 \mathrm{~m}, 1239 \mathrm{~m}, 1218 \mathrm{~s}$, $1170 \mathrm{w}, 1107 \mathrm{w}, 1081 \mathrm{~m}, 1034 \mathrm{~m}, 967 \mathrm{~m}, 916 \mathrm{w}, 843 \mathrm{vs}, 739 \mathrm{~s}$, 626w, $558 \mathrm{~m}$.

\section{X-Ray crystallography}

$\mathrm{X}$-ray diffraction measurements were performed on a STOE IPDS II diffractometer, operating with Mo-K $\alpha$ $(\lambda=0.71073 \AA) \mathrm{X}$-ray tube with graphite monochromator. The structures were solved by direct methods (using SHELXS-2013 or SHELXS-2014 crystallographic software) and refined by full-matrix least squares techniques based on $F^{2}$. The non-H atoms were refined with anisotropic displacement parameters. Calculations were performed using SHELXL-2018 or SHELXL-2014 crystallographic software package. A summary of the crystallographic data and the structure refinement for the three compounds are given in Table 1. CCDC reference numbers: 2000488-2000490.

Table 1

Crystallographic data, details of data collection and structure refinement parameters for compounds $\mathbf{1 - 3}$

\begin{tabular}{llll}
\hline Compound & \multicolumn{1}{c}{$\mathbf{1}$} & \multicolumn{1}{c}{$\mathbf{2}$} & \multicolumn{1}{c}{$\mathbf{3}$} \\
\hline Chemical formula & $\mathrm{C}_{30} \mathrm{H}_{33} \mathrm{~N}_{4} \mathrm{O}_{6} \mathrm{Er}$ & $\mathrm{C}_{30} \mathrm{H}_{33} \mathrm{~N}_{4} \mathrm{O}_{6} \mathrm{Yb}$ & $\mathrm{C}_{36} \mathrm{H}_{46} \mathrm{ErF}_{6} \mathrm{~N}_{8} \mathrm{O}_{6} \mathrm{P}$ \\
$M\left(\mathrm{~g} \mathrm{~mol}^{-1}\right)$ & 712.86 & 718.64 & 999.04 \\
Temperature, $(\mathrm{K})$ & $293(2)$ & $293(2)$ & $173(2)$ \\
Wavelength, $(\AA)$ & 0.71073 & 0.71073 & 0.71073 \\
Crystal system & Trigonal & Trigonal & Trigonal \\
Space group & $P-3$ & $P-3$ & $R-3$ \\
$a(\AA)$ & $14.0384(14)$ & $13.9972(8)$ & $13.0523(18)$ \\
$b(\AA)$ & $14.0384(14)$ & $13.9972(8)$ & $13.0523(18)$ \\
$c(\AA)$ & $8.2966(8)$ & $8.3337(4)$ & $43.514(9)$ \\
$\alpha\left({ }^{\circ}\right)$ & 90 & 90 & 90 \\
$\beta\left({ }^{\circ}\right)$ & 90 & 90 & 90 \\
$\gamma\left({ }^{\circ}\right)$ & 120 & 120 & 120 \\
$V\left(\AA^{3}\right)$ & $1416.0(3)$ & $1414.00(18)$ & $6420(2)$ \\
$\mathrm{Z}$ & 2 & 2 & 6 \\
$\left.D_{\mathrm{c}}(\mathrm{g} \mathrm{cm})^{-3}\right)$ & 1.672 & 1.688 & 1.550 \\
$\mu\left(\mathrm{mm}^{-1}\right)$ & 3.014 & 3.358 & 2.076 \\
$\mathrm{~F}(000)$ & 714 & 718 & 3018 \\
Goodness-of-fit on $F^{2}$ & 1.068 & 1.091 & 1.039 \\
\hline
\end{tabular}


Table 1 (continued)

\begin{tabular}{llll}
\hline Final $R 1, w R_{2}[I>2 \sigma(I)]$ & $0.0720,0.1449$ & $0.0402,0.0823$ & $0.0546,0.1189$ \\
$R 1, w R_{2}$ (all data) & $0.1153,0.1712$ & $0.0609,0.0906$ & $0.0773,0.1306$ \\
Largest diff. peak and hole $\left(\mathrm{e} \AA^{-3}\right)$ & $3.526,-1.094$ & $0.966,-0.547$ & $2.072,-1.454$ \\
\hline
\end{tabular}

Physical measurements. The IR spectra ( $\mathrm{KBr}$ pellets) were collected on a Bruker Tensor 37 spectrophotometer in the $4000-400 \mathrm{~cm}^{-1}$ range.

\section{CONCLUSIONS}

In this article, we describe the crystal structures of the mononuclear complexes [Er(valtren)] and $[\mathrm{Yb}($ valtren $)]$ containing the bicompartmental tripodal Schiff base ligand derived from $o$-vanillin and tris(2-aminoethyl)-amine. The [Er(valtren)] complex proved to be a good receptor for the ammonium cation, which is encapsulated in the external compartment of the ligand by hydrogen interactions.

Acknowledgements. Financial support from the UEFISCDI (Project PN-II-RU-TE-2011-3-0252 nr. 33/2011) is gratefully acknowledged.

\section{REFERENCES}

1. (a) J.-P. Costes, F. Dahan, A. Dupuis and J.-P. Laurent, Inorg. Chem., 1996, 35, 2400; (b) M. Andruh, Chem. Commun., 2007, 2565; (c) M. Andruh, Chem. Commun., 2011, 47, 3025.

2. (a) D. G. Branzea, A. Guerri, O. Fabelo, C. Ruiz-Pérez, L.-M. Chamoreau, C. Sangregorio, A. Caneschi and M. Andruh, Cryst. Growth Des., 2008, 8, 941; (b) D. G. Branzea, L. Sorace, C. Maxim, M. Andruh and A. Caneschi, Inorg. Chem., 2008, 47, 6590; (c) M. Nayak, R. Koner, H.-H. Lin, U. Flörke, H.-H. Wei and S. Mohanta, Inorg. Chem., 2006, 45, 10764.

3. (a) S. Nastase, F. Tuna, C. Maxim, C. A. Muryn, N. Avarvari, R. E. P. Winpenny and M. Andruh, Cryst. Growth Des., 2007, 7, 1825; (b) M. Á. VázquezFernández, M. I. Fernández-García, A. M. GonzálezNoya, M. Maneiro, M. R. Bermejo and M. J. RodríguezDoutón, Polyhedron, 2012, 31, 379; (c) C. D. Ene, S. Nastase, C. Maxim, A. M. Madalan, F. Tuna and M. Andruh, Inorg. Chim. Acta, 2010, 363, 4247.
4. (a) A. M. Madalan, N. Avarvari and M. Andruh, New J. Chem., 2006, 30, 521; (b) S. Harza, R. Koner, M. Nayak, H. A. Sparkes, J. A. K. Howard and S. Mohanta, Cryst. Growth Des., 2009, 9, 3603.

5. A. Cucos, A. Ursu, A. M. Madalan, C. Duhayon, J.-P. Sutter and M. Andruh, CrystEngComm, 2011, 13, 3756.

6. A. M. Madalan and C. D. Ene, Inorg. Chim. Acta, 2018, $475,184$.

7. (a) A. M. Pujol, C. Gateau, C. Lebrun and P. Delangle, Chem. Eur. J., 2011, 17, 4418; (b) F. E. Hahn, H. Schröder, T. Pape and F. Hupka, Eur. J. Inorg. Chem., 2010, 909; (c) Z. Dai and J. W. Canary, New. J. Chem, 2007, 31, 1708; (d) T. Shiga and H. Oshio, Polyhedron, 2007, 26, 1881; (e) S. M. Cohen, S. Petoud and K. N. Raymond, Inorg. Chem., 1999, 38, 4522.

8. (a) J.-P. Costes and F. Nicodème, Chem. Eur. J., 2002, 8, 3442; (b) J.-P. Costes, F. Dahan and F. Nicodème, Inorg. Chem., 2003, 42, 6556; (c) S. Mizukami, H. Houjou, M. Kanesato and K. Hiratani, Chem. Eur. J., 2003, 9, 1521; (d) S. J. Archibald, A. J. Blake, S. Parsons, M. Schröder and R. E. P. Winpenny, J. Chem. Soc., Dalton Trans., 1997, 173; (e) X.-L. Zheng, Y. Liu, M. Pan, X.-Q. Lü, J.Y. Zhang, C.-Y. Zhao, Y.-X. Tong and C.-Y. Su, Angew. Chem. Int. Ed., 2007, 46, 7399; (f). M. Pan, M.-H. Lan, X.-T. Wang, C. Yan, Y. Liu and C.-Y. Su, Inorg. Chim. Acta, 2010, 363, 3757; (g) C. Kachi-Terajima, K. Yanagi, T. Kaziki, T. Kitazawa and M. Hasegawa, Dalton Trans., 2011, 40, 2249; (h) E. Vulpe and A. M. Madalan, Rev. Roum. Chim., 2013, 58, 823.

9. (a) L. O. Abouderbala, W. J. Belcher, M. G. Boutelle, P. J. Cragg, J. W. Steed, D. R. Turner and K. J. Wallace, $P$. Natl. Acad. Sci. U.S.A., 2002, 99, 5001; (b) M. A. Hossain, J. A. Lijegren, D. Powell and K. BowmanJames, Inorg. Chem., 2004, 43, 3751; (c) R. J. Warr, A. N. Westra K. J. Bell, J. Chartres, R. Ellis, C. Tong, T. G. Simmance, A. Gadzhieva, A. J. Blake, P. A. Tasker and M. Schröder, Chem. Eur. J., 2009, 15, 4836; (d) A. Metzger, V. M. Lynch and E. V. Aslyn, Angew. Chem. Int. Ed., 1997, 36, 862.

10. R. Cao, P. Müller and S. J. Lipard, J. Am. Chem. Soc., 2010, 132, 17366.

11. E. Lucaccini, J. J. Baldoví, L. Chelazzi, A.-L. Barra, F. Grepioni, J.-P. Costes and L. Sorace, Inorg. Chem., 2017, 56, 4728. 
